\title{
SOURCES OF POTASSIUM IN THE FERTILIZATION OF AGATA POTATO
}

\author{
FONTES DE POTÁSSIO NA FERTILIZAÇÃO DA BATATA ÁGATA
}

\author{
Roberta Camargos OLIVEIRA ${ }^{\mathbf{1}}$; José Magno Queiroz LUZ ${ }^{\mathbf{2}}$; \\ Rodrigo Ribeiro CARDOSO ${ }^{3}$; Regina Maria Quintão LANA ${ }^{2}$; Jarbas dos Reis SILVA ${ }^{3}$ \\ 1. Pós-doutorando em Agronomia Instituto de Ciências Agrárias da Universidade Federal de Uberlândia-ICIAG-UFU, Uberlândia, MG, \\ Brasil, robertacamargoss@gmail.com; 2. Professor do ICIAG-UFU, Uberlândia, MG, Brasil; 3. Agrícola Wehrmann, Cristalina-GO, \\ Brasil
}

\begin{abstract}
The potato plant presents extraordinary productive capacity, being the fertilization one of the essential factors to optimize the cultivars potential. Potassium (K), the nutrient most absorbed and transported by the crop, interferes with the productivity and tubers quality. Despite many efforts to improve the general and nutritional management of the crop, information as $\mathrm{K}$ source and its parceling are still not well elucidated, generating doubts to the producers regarding the decision making. The aim of this study was to evaluate the development, productivity and potatoes quality in relation to sources and proportions of potassic fertilization and its subdivision. The field experiment were conducted with the Agate variety, in the municipalities of Ibicoara - BA and São Gotardo - MG. The design was in randomized blocks, in factorial 6X2, with four replications. The treatments consisted of the combination of potassium chloride and double sulfate of potassium and magnesium $\left(100 \% \mathrm{KCl} ; 87.5 \% \mathrm{KCl}+12.5 \% \mathrm{~K}_{2} \mathrm{SO}_{4} .2 \mathrm{MgSO}_{4} ; 75 \% \mathrm{KCl}+25 \% \mathrm{~K}_{2} \mathrm{SO}_{4} .2 \mathrm{MgSO}_{4}\right.$; $50 \% \mathrm{KCl}+50 \% \mathrm{~K}_{2} \mathrm{SO}_{4} \cdot 2 \mathrm{MgSO}_{4} ; 25 \% \mathrm{KCl}+75 \% \mathrm{~K}_{2} \mathrm{SO}_{4} \cdot 2 \mathrm{MgSO}_{4}$ and $\left.100 \% \mathrm{~K}_{2} \mathrm{SO}_{4} \cdot 2 \mathrm{MgSO}_{4}\right)$ of the potassium recommended amount $(100 \%$ at planting or $50 \%$ at planting and $50 \%$ at the beginning of tuberization). The proportion of potassium fertilizer sources in São Gotardo-MG does not affect the vegetative development at 60 days after planting (DAP) and potato productivity. In Ibicoara-BA, plants fertilized with $100 \% \mathrm{KCl}$ reduced the amount of discarded tubers and presented aerial dry mass (MSA) accumulation $41 \%$ higher than the application of $50 \% \mathrm{KCl}$ and $50 \% \mathrm{~K}_{2} \mathrm{SO}_{4} \cdot 2 \mathrm{MgSO}_{4}$. The $\mathrm{K}$ subdivision is favorable to special tuber classes in São Gotardo-MG and reduces the class Discard in Ibicoara-BA. Most of the proportions between $\mathrm{K}_{2} \mathrm{SO}_{4} \cdot 2 \mathrm{MgSO}_{4}$ and $\mathrm{KCl}$ did not differ from the exclusive use of $\mathrm{KCl}$ for the quantitative parameters. On the other hand, qualitative factors such as starch and soluble solids are related to the application of $100 \%$ of $\mathrm{K}$ via $\mathrm{K}_{2} \mathrm{SO}_{4} .2 \mathrm{MgSO}_{4}$ in installments.
\end{abstract}

KEYWORDS: Solanum tuberosum. Double potassium and magnesium sulfate. Potassium chloride.

\section{INTRODUCTION}

Potato (Solanum tuberosum L.) is the vegetable-growing with the largest cultivated area in Brazil (TÖFOLI et al., 2013). It is an important source of bioactive compounds, as it has a high index of phenolic acids, anthocyanins and carotenoids (EZEQUIEL et al., 2013). The ingestion of these phytochemicals is related to the prevention of chronic diseases, inflammations and diabetes (ACOSTA-ESTRADA et al., 2014), which increases the interest of the research of this culture in order to meet the demand of a population concerned about health food.

Most of the Brazilian potato production is destined for in natura consumption, with the Agate cultivar being widely produced in several states of the country. Among the management factors that potentiate the crop results, the fertilization contributes in a decisive way to increase productivity and quality. It is essential to understand the process and specificities of the potato production chain, because, despite the relatively short cycle; the potato presents a high nutrients requirement needing to be available in the soil solution (FERNANDES; SORATTO, 2012).

Well-nourished plants are able to withstand stress conditions, both biotic and abiotic. Potassium $(\mathrm{K})$ is the nutrient most absorbed by the potato. $\mathrm{K}$ is also related to several biochemical and physiological processes that influence growth and metabolism (WANG et al., 2014), release of energy molecules for plant defense (DEMIDCHIK, 2014) and signaling that mediates several adaptive responses of plants to the environment (ANSCHÜTZ, 2014). The tubers export large amounts of $\mathrm{K}$, reaching 1.8 times higher than $\mathrm{N}$ and 10 times higher than $\mathrm{P}$, with variations between cultivars and availability of nutrients in the soil (FERNANDES; SORATTO, 2012). 
Although it is known that $\mathrm{K}$ is fundamental in the efficiency and the economics of water use, research emphasizes the necessity to study the interaction between the macro-ecological factors that affect the optimal use of this nutrient (SARDANS; PEÑUELAS, 2015).

Physiological and molecular responses have been entirely attributed to $\mathrm{K}$ but the accompanying anion $\left(\mathrm{Cl}^{-}, \mathrm{SO}_{4}{ }^{2-}\right.$ or others $)$ has been little considered (ARMENGAUD et al., 2004; BENLLOCHGONZALEZ et al., 2008).

$\mathrm{K}$ is supplied predominantly via potassium chloride $(\mathrm{KCl}) . \mathrm{Cl}^{-}$is a micronutrient that plays specific roles in regulating leaf osmotic potential and turgor, allowing plants to improve leaf water balance which results in lower water loss and greater photosynthetic and integrated water-use efficiency (FRANCO-NAVARRO et al., 2016). In addition, $\mathrm{Cl}^{-}$in high levels can compete with others essential anionic macronutrients such as nitrate, sulphate, and phosphate (FRANCO-NAVARRO et al., 2016).

There are several possible molecular mechanisms of $\mathrm{Cl}^{-}$uptake and translocation in plants (SUN et al., 2014). The action of $\mathrm{Cl}^{-}$on the plant, however, is variable among species. Lam et al. (2015) observed that within a single family of plants, some species showed positive action on the presence of $\mathrm{Cl}^{-}$, while in others no evidence was found.

In addition to chloride, $\mathrm{K}$ can be supplied from the source combined with sulfate, which provides one or more other essential macronutrients, such as double magnesium and potassium sulfate, which provides $\mathrm{Mg}$ and $\mathrm{S}$. These sources, however, present higher prices and lower concentrations and availabilities. Therefore, it is an interesting alternative to combine proportions between chloride and sulfate to dilute the cost and obtain the advantages of each source.

Thus, the objective of this work was to evaluate the development, productivity and quality of Agate potato tubers as a function of proportions between sources of potassium fertilization and its subdivision.

\section{MATERIAL AND METHODS}

Two experiments were conducted with the Agate cultivar, in São Gotardo-MG, between December 2009 and March 2010 and Ibicoara-BA, between February and May 2010.

The soil chemical characteristics in the 0-20 cm layer in Ibicoara-BA were: $\mathrm{pH} \mathrm{H}_{2} \mathrm{O}=5.0 ; \mathrm{P}$ Mehlich $=25 \mathrm{mg} \mathrm{dm}^{-3} ; \mathrm{K}=0.29 \mathrm{cmolc} \mathrm{dm}^{-3} ; \mathrm{Ca}=$ $4.5 \mathrm{cmolc} \mathrm{dm}^{-3} ; \mathrm{Mg}=0.8 \mathrm{cmolc} \mathrm{dm}^{-3} ; \mathrm{Al}=0.1 \mathrm{cmol}$ $\mathrm{dm}^{-3}$ and $\mathrm{V}=51 \%$. In São Gotardo-MG were $\mathrm{pH}$ $\mathrm{H}_{2} \mathrm{O}=5.4 ; \mathrm{P}$ Mehlich $=50 \mathrm{mg} \mathrm{dm}^{-3} ; \mathrm{K}=0.5 \mathrm{cmolc}$ $\mathrm{dm}^{-3} ; \mathrm{Ca}=3.8 \mathrm{cmol} \mathrm{dm}^{-3} ; \mathrm{Mg}=0.6 \mathrm{cmolc} \mathrm{dm}^{-3} ; \mathrm{Al}$ $=0.1 \mathrm{cmolc} \mathrm{dm}^{-3}$ and $\mathrm{V}=60 \%$, both with medium texture.

The design was a randomized complete block, with treatments in a $6 \times 2$ factorial and four replications, totaling 48 plots. The treatments consisted of six combinations between two sources of potassium fertilizer ( $\mathrm{KCl}$ and $\mathrm{K}_{2} \mathrm{SO}_{4} \cdot 2 \mathrm{MgSO}_{4}$ ), applied $100 \%$ at planting or $50 \%$ at planting and the remainder at the beginning of tuberization. The combinations are in Table 1.

Table 1. Description of treatments (proportions between potassium fertilizer sources ( $\mathrm{KCl}$ and $\mathrm{K}_{2} \mathrm{SO}_{4} \cdot 2 \mathrm{MgSO}_{4}$ ).

\begin{tabular}{ccc}
\hline Treatments & $\mathrm{KCl}$ & $\mathrm{K}_{2} \mathrm{SO}_{4} \cdot 2 \mathrm{MgSO}_{4}$ \\
\cline { 2 - 4 } & & Rates in \% \\
2 & 100 & 0 \\
3 & 87,5 & 12,5 \\
4 & 75 & 25 \\
5 & 50 & 50 \\
6 & 25 & 75 \\
\hline
\end{tabular}

The nutrient rates applied to the soil in the planting groove were: $140 \mathrm{~kg} \mathrm{ha}^{-1}$ of $\mathrm{N}$ (Urea, with $45 \% \mathrm{~N}$ ) and $700 \mathrm{~kg} \mathrm{ha}^{-1}$ of $\mathrm{P}_{2} \mathrm{O}_{5}$ (triple super phosphate, with $41 \%$ of $\mathrm{P}_{2} \mathrm{O}_{5}$ ). Potassium was 300 $\mathrm{kg} \mathrm{ha}{ }^{-1}$ of $\mathrm{K}_{2} \mathrm{O}$ in a combinations of potassium chloride $\left(60 \%\right.$ of $\left.\mathrm{K}_{2} \mathrm{O}\right)$ and double sulfate of potassium and magnesium $\left(21 \%\right.$ of $\left.\mathrm{K}_{2} \mathrm{O}\right)$, constituting the treatments (Table 1).

Each plot was constituted by four lines, spaced in $0.80 \mathrm{~m}$, with six $\mathrm{m}$ of length, totaling 19.2 $\mathrm{m}^{2}$ of total area per plot. The evaluations were carried out in the two central lines, which comprised 
the useful area, neglecting the initial and final halfmeters of each plot.

The areas were prepared according to conventional potato crop, with two plows and two harrows. The fertilizer distribution in the planting groove was done manually, and later the mechanized distribution of seed potatoes type three (tubers with 30 to 40 millimeters in diameter) was carried out along with application of protective fungicides and insecticide.

At sixty days after planting, one plant was removed per plot to analyze plant development. Plants with competitive sides and absence of virus symptoms were collected. In the laboratory the plants were separated into leaves, stems, and tubers, and the aerial, root, and tubers fresh masses were quantified using an analytical balance with the weight expressed in grams; the length of the largest stem, using a millimeter tape; and the number of stems and tubers. The samples were packed in paper bags, weighed, placed in an oven with forced ventilation and maintained at 65 degrees for 96 hours. After drying, the samples were again weighed, obtaining aerial, root and tubers dry mass.

At the time of harvesting, tubers of useful area were classified according to transverse diameter: Special (above 33mm), Second (28$33 \mathrm{~mm}$ ), Diverse (up to $28 \mathrm{~mm}$ ), Doll (tubers with some physiological disturbance) and discard (noncommercial tubers).

After being classified, the tubers were weighed in an analytical balance to obtain the amount of mass per plot. The results were transformed to yield per hectare. The sum of the Special, Second and Diverse classes formed the total productivity.

The phytosanitary treatment carried out during the entire crop development was based on pests and diseases monitoring used in commercial farming. The products used to control pests, diseases and weeds are recorded for potato cultivation and were applied at the recommended doses.

The soluble solids content was determined by the densimeter technique. In this technique, a sample of $3.63 \mathrm{~kg}$ of tubers was randomly collected from the tubers harvested in each plot. The material was immersed in a tank with a capacity of 100 liters of water, obtaining the submerged weight. From the calculations, the specific weight of each sample was obtained, and was related to the content of solids soluble in percentage.

The starch was determined according to the methodology described by Somogyi, adapted by Nelson (1944), reading at spectrophotometer (535nm).

The results were submitted for variance analysis. Those that presented significant difference for the $F$ test were submitted to a comparison of means by Tukey test at 0.5 probability, using the SISVAR statistical program.

\section{RESULTS AND DISCUSSION}

\section{Vegetative development at 60 days after planting (DAP)}

In both experiments evaluated, the characteristics observed at sixty days did not show interaction between the proportions of potassium fertilizer and its partitioning. In São Gotardo-MG, the combination between potassium sulphate and potassium chloride and the division of the applied amount (planting and cover) did not favor significantly the factors that express plants development (Table 2).

The treatments, in this location, provided an average production, approximately of ten to thirteen tubers. The plants had about two to three stems, with 59 to $88 \mathrm{~cm}$ of height, root, aerial and tubers fresh mass of respectively: 34 to 76 ; 660 to 750 ; and 700 to $860 \mathrm{~g}$ plant $^{-1}$, and aerial, root and tubers dry mass around of respectively: 83 to $105 ; 26$ to 36 ; and 71 to 137 g plant $^{-1}$ (Table 2).

Table 2. Agronomic characteristics of the potato crop at 60 days after planting in São Gotardo-MG

\begin{tabular}{|c|c|c|c|c|c|c|c|c|c|}
\hline Treatments & $\begin{array}{l}\text { Tubers } \\
\text { number }\end{array}$ & $\begin{array}{c}\text { Stems } \\
\text { number }\end{array}$ & height & $\mathrm{AFM}^{1}$ & RFM & TFM & $\mathrm{ADM}$ & RDM & TDM \\
\hline & & & $\mathrm{cm}$ & \multicolumn{6}{|c|}{ g plant $^{-1}$} \\
\hline 1 & $12.37 \mathrm{a}^{*}$ & $2.50 \mathrm{a}$ & $88.00 \mathrm{a}$ & $750 a$ & $41 \mathrm{a}$ & $810 \mathrm{a}$ & $105.00 \mathrm{a}$ & $26 \mathrm{a}$ & $97.20 \mathrm{a}$ \\
\hline 2 & $11.00 \mathrm{a}$ & $2.12 \mathrm{a}$ & $82.75 a$ & $660 a$ & $76 a$ & $700 a$ & $89.10 \mathrm{a}$ & $32 \mathrm{a}$ & $94.50 \mathrm{a}$ \\
\hline 3 & $11.37 \mathrm{a}$ & $2.37 \mathrm{a}$ & $73.25 \mathrm{a}$ & $670 \mathrm{a}$ & $34 a$ & $770 \mathrm{a}$ & $87.10 \mathrm{a}$ & $26 a$ & $77.00 \mathrm{a}$ \\
\hline 4 & $10.37 \mathrm{a}$ & $2.25 \mathrm{a}$ & $81.12 \mathrm{a}$ & $670 \mathrm{a}$ & $34 a$ & $750 \mathrm{a}$ & $83.75 \mathrm{a}$ & $30 \mathrm{a}$ & $71.25 \mathrm{a}$ \\
\hline 5 & $12.00 \mathrm{a}$ & $2.50 \mathrm{a}$ & $59.00 \mathrm{a}$ & $680 \mathrm{a}$ & $42 a$ & $720 \mathrm{a}$ & $91.80 \mathrm{a}$ & $36 a$ & $97.20 \mathrm{a}$ \\
\hline 6 & $12.75 \mathrm{a}$ & $2.25 \mathrm{a}$ & $82.00 \mathrm{a}$ & $740 \mathrm{a}$ & $39 a$ & $860 a$ & $92.50 \mathrm{a}$ & $31 \mathrm{a}$ & $137.60 \mathrm{a}$ \\
\hline
\end{tabular}

* Means followed by the same letter did not differ from each other by Tukey test at 0.05 . CV: coefficient of variation; ${ }^{1}$ AFM: aerial fresh mass; RFM: root fresh mass; TFM: tuber fresh mass; $\mathrm{ADM}$ : aerial dry mass; $\mathrm{RDM}$ : root dry mass; $\mathrm{TDM}$ : tuber dry mass. $\mathrm{T} 1=100 \% \mathrm{KCl}, \mathrm{T} 2=87.5 \% \mathrm{KCl}+12.5 \%$ $\mathrm{K}_{2} \mathrm{SO}_{4} \cdot 2 \mathrm{MgSO}_{4}, \mathrm{~T} 3=75 \% \mathrm{KCl}+25 \% \mathrm{~K}_{2} \mathrm{SO}_{4} \cdot 2 \mathrm{MgSO}_{4}, \mathrm{~T} 4=50 \% \mathrm{KCl}+50 \% \mathrm{~K}_{2} \mathrm{SO}_{4} \cdot 2 \mathrm{MgSO}_{4}, \mathrm{~T} 5=25 \% \mathrm{KCl}+75 \% \mathrm{~K} \mathrm{SO}_{4} .2 \mathrm{MgSO}, \mathrm{T} 6=100 \%$ $\mathrm{K}_{2} \mathrm{SO}_{4} \cdot 2 \mathrm{MgSO}_{4}$. 
In Ibicoara-BA, $75 \% \quad \mathrm{KCl}$ and $25 \%$ $\mathrm{K}_{2} \mathrm{SO}_{4} \cdot 2 \mathrm{MgSO}_{4}$ was related to lowest fresh root mass. However, after water removal, it was observed that there was no difference among the sources proportions. Thus, a change in water accumulation in root system related to $\mathrm{K}$ source was observed in which $100 \% \mathrm{KCl}$ favored water accumulation, $53.4 \%$, compared to $100 \%$ $\mathrm{K}_{2} \mathrm{SO}_{4} \cdot 2 \mathrm{MgSO}_{4}$ (Table 3). Besides a role as an unspecific cell osmoticum, no clear biological roles have been explicitly associated with $\mathrm{Cl}^{-}$ accumulation (FRANCO-NAVARRO et al., 2016).

On the other hand, $\mathrm{Cl}^{-}$movement within the soil is determined by water fluxes, and in particular the relationship between precipitation and evapotranspiration. In tropical areas such as Brazil, high rainfall often results in thorough leaching of $\mathrm{Cl}^{-}$(CHEN et al., 2010), providing higher absorption sulfate.

Interactions of sulfate with other nutrients have been studied recently under sulfate deprivation and $\mathrm{H}_{2} \mathrm{~S}$ fumigation (REICH et al., 2016) and under sulfate excess (AGHAJANZADEH et al.; 2017). The decrease of one anion in plant tissue could be caused by an electrochemical antagonism and by a control of the gene expression of ion-transporters (AGHAJANZADEH et al., 2017).

Aerial dry mass (ADM) presented a similar response, but with a worse vegetative growth performance when both sources presented equal proportions $(50 \%)$. Plants that received $100 \% \mathrm{KCl}$ presented an accumulation of ADM $41 \%$ higher than fertilized plants with $50 \% \mathrm{KCl}$ and $50 \%$ $\mathrm{K}_{2} \mathrm{SO}_{4} \cdot 2 \mathrm{MgSO}_{4}$ (Table 3). There was a distinct behavior between water and dry mass accumulation between the root system and aerial part of potato in Ibicoara-BA. Such a relationship may be linked to internal processes, such as distinct physiological stages between shoot and root.

External factors such as some interaction between the water content, nutrients and other characteristics related to soil and climate of the location can also interact and influence plants response. The difference between the cultivar response in the Brazilian regions may be related to soil constituents, source material, and degree of weathering, since these factors substantially reflect the effect of clay minerals on $\mathrm{K}$ retention or release (AL-OBAIDI , et al., 2014, ZORB et al., 2014).

Table 3. Agronomic characteristics of the potato crop at 60 days after planting in Ibicoara-BA.

\begin{tabular}{|c|c|c|c|c|c|c|c|c|c|}
\hline Treatments & $\begin{array}{c}\text { Tubers } \\
\text { number }\end{array}$ & $\begin{array}{c}\text { Stems } \\
\text { number }\end{array}$ & height & $\mathrm{AFM}^{1}$ & RFM & TFM & ADM & RDM & TDM \\
\hline & & & $\mathrm{cm}$ & \multicolumn{6}{|c|}{ g planta $^{-1}$} \\
\hline 1 & $4.12 \mathrm{a}$ & $16.37 \mathrm{a}$ & $88.87 \mathrm{a}$ & $790 \mathrm{a}$ & $89 a$ & $980 \mathrm{a}$ & $110.6 \mathrm{a}$ & $26 a$ & $230 \mathrm{a}$ \\
\hline 2 & $4.37 \mathrm{a}$ & $15.25 \mathrm{a}$ & $85.25 \mathrm{a}$ & $620 \mathrm{a}$ & $67 \mathrm{ab}$ & $760 \mathrm{a}$ & 86.8ab & $19 a$ & $170 \mathrm{a}$ \\
\hline 3 & $3.50 \mathrm{a}$ & $12.62 \mathrm{a}$ & $86.75 a$ & $530 \mathrm{a}$ & $51 b$ & $850 \mathrm{a}$ & $86 a b$ & $15 \mathrm{a}$ & $120 \mathrm{a}$ \\
\hline 4 & $4.87 \mathrm{a}$ & $13.75 \mathrm{a}$ & $80.50 \mathrm{a}$ & $520 \mathrm{a}$ & $69 \mathrm{ab}$ & $890 \mathrm{a}$ & $78 b$ & $23 a$ & $200 a$ \\
\hline 5 & $4.62 \mathrm{a}$ & $15.50 \mathrm{a}$ & $76.87 \mathrm{a}$ & $630 \mathrm{a}$ & $67 \mathrm{ab}$ & $860 \mathrm{a}$ & $101 \mathrm{ab}$ & $21 \mathrm{a}$ & $220 \mathrm{a}$ \\
\hline 6 & $4.37 \mathrm{a}$ & $14.75 \mathrm{a}$ & $76.00 \mathrm{a}$ & $470 \mathrm{a}$ & $58 \mathrm{ab}$ & $760 \mathrm{a}$ & $96 a b$ & $17 \mathrm{a}$ & $160 \mathrm{a}$ \\
\hline
\end{tabular}

* Means followed by the same letter did not differ from each other by Tukey test at 0.05 . CV: coefficient of variation. ${ }^{1}$ AFM: aerial fresh mass; RFM: root fresh mass; TFM: tuber fresh mass; ADM: aerial dry mass; RDM: root dry mass; TDM: tuber dry mass. T1 = $100 \% \mathrm{KCl}, \mathrm{T} 2=87.5 \% \mathrm{KCl}+12.5 \% \mathrm{~K}_{2} \mathrm{SO}_{4} .2 \mathrm{MgSO}_{4}, \mathrm{~T} 3=75 \% \mathrm{KCl}+25 \% \mathrm{~K}_{2} \mathrm{SO}_{4} .2 \mathrm{MgSO}_{4}, \mathrm{~T} 4=50 \% \mathrm{KCl}+50 \% \mathrm{~K}_{2} \mathrm{SO}_{4} .2 \mathrm{MgSO}_{4}$, $\mathrm{T} 5=25 \% \mathrm{KCl}+75 \% \mathrm{~K}_{2} \mathrm{SO}_{4} \cdot 2 \mathrm{MgSO}_{4}, \mathrm{~T} 6=100 \% \mathrm{~K}_{2} \mathrm{SO}_{4} \cdot 2 \mathrm{MgSO}_{4}$

The treatments provided an average yield about of three to five tubers. The plants had around twelve to sixteen stems, with 76 to $88.87 \mathrm{~cm}$ of height, aerial and tubers fresh mass of respectively: 470 to 790 and 760 to $980 \mathrm{~g}$ plant $^{-1}$, and root and tubers dry mass of respectively: 15 to 26 and 120 to $230 \mathrm{~g}$ plant $^{-1}$ (Table 3 ).

Cardoso et al. (2007) working with rates (75; 100 and $125 \%$ of recommended rate) and application times (combination of planting; upon planting and tuberization) of $\mathrm{N}$ and $\mathrm{K}$ in Chapada Diamantina (Bahia) region, also did not find significant variations in the number of tubers.

\section{Harvest and tubers classification}

There was no interaction between the proportion of potassium fertilizer and its partitioning in the 'Agate' yield, in both locations studied.

The variation in potassium fertilizer did not affect the 'Agate' yield in São Gotardo-MG (Table 4). On the other hand, the installments were favorable to the special class production, with a $20.3 \%$ increase in yield, being the fragmented application of total potassic fertilizer rate viable option in locations with soil and climate characteristics close to those of São Gotardo-MG (Table 5). Specifically it has been reported that 50\% 
of the applied fertilizer can be leached below $0.6 \mathrm{~m}$ in soil profile (ROSOLEM et al., 2013), a depth greater than absorption capacity by the potato root system.

Table 4. Potato tubers yield cultivated with $\mathrm{K}$ sources proportions $\left(\mathrm{KCl}\right.$ and $\left.\mathrm{K}_{2} \mathrm{SO}_{4} \cdot 2 \mathrm{MgSO}_{4}\right)$ in São GotardoMG.

\begin{tabular}{ccrcccc}
\hline Treatments & Special & Second & Diverse & Doll & Discard & $\begin{array}{c}\text { Total } \\
\text { commercial }\end{array}$ \\
\hline & & \multicolumn{7}{c}{$\mathrm{t} \mathrm{ha}^{-1}$} \\
2 & $15.73 \mathrm{a} *$ & $7.88 \mathrm{a}$ & $6.55 \mathrm{a}$ & $0.71 \mathrm{a}$ & $2.27 \mathrm{a}$ & $30.87 \mathrm{a}$ \\
3 & $15.61 \mathrm{a}$ & $8.46 \mathrm{a}$ & $7.20 \mathrm{a}$ & $0.43 \mathrm{a}$ & $1.85 \mathrm{a}$ & $31.71 \mathrm{a}$ \\
4 & $14.20 \mathrm{a}$ & $10.87 \mathrm{a}$ & $9.08 \mathrm{a}$ & $0.51 \mathrm{a}$ & $2.20 \mathrm{a}$ & $34.67 \mathrm{a}$ \\
5 & $15.22 \mathrm{a}$ & $9.63 \mathrm{a}$ & $6.63 \mathrm{a}$ & $0.38 \mathrm{a}$ & $2.00 \mathrm{a}$ & $31.88 \mathrm{a}$ \\
6 & $17.65 \mathrm{a}$ & $9.52 \mathrm{a}$ & $6.58 \mathrm{a}$ & $0.71 \mathrm{a}$ & $1.52 \mathrm{a}$ & $34.47 \mathrm{a}$ \\
\hline
\end{tabular}

* Means followed by the same letter did not differ from each other by Tukey test at 0.05 . CV: coefficient of variation. $\mathrm{T} 1=100 \% \mathrm{KCl}$, $\mathrm{T} 2=87.5 \% \mathrm{KCl}+12.5 \% \mathrm{~K}_{2} \mathrm{SO}_{4} .2 \mathrm{MgSO}_{4}, \mathrm{~T} 3=75 \% \mathrm{KCl}+25 \% \mathrm{~K}_{2} \mathrm{SO}_{4} .2 \mathrm{MgSO}_{4}, \mathrm{~T} 4=50 \% \mathrm{KCl}+50 \% \mathrm{~K}_{2} \mathrm{SO}_{4} .2 \mathrm{MgSO}_{4}, \mathrm{~T} 5=25 \%$ $\mathrm{KCl}+75 \% \mathrm{~K}_{2} \mathrm{SO}_{4} \cdot 2 \mathrm{MgSO}_{4}, \mathrm{~T} 6=100 \% \mathrm{~K}_{2} \mathrm{SO}_{4} \cdot 2 \mathrm{MgSO}_{4}$

Table 5. Potato tubers yield cultivated with or without $\mathrm{K}$ installments (100\% at planting or $50 \%$ at planting and $50 \%$ at beginning of tuberization) in São Gotardo-MG.

\begin{tabular}{ccccccc}
\hline Treatments & Special & Second & Diverse & Doll & Discard & Total commercial \\
\hline With & $17.18 \mathrm{a}^{*}$ & $8.37 \mathrm{~b}$ & $7.20 \mathrm{a}$ & $0.63 \mathrm{a}$ & $1.73 \mathrm{a}$ & $33.40 \mathrm{a}$ \\
Without & $14.28 \mathrm{~b}$ & $10.87 \mathrm{a}$ & $6.86 \mathrm{a}$ & $0.45 \mathrm{a}$ & $1.96 \mathrm{a}$ & $32.47 \mathrm{a}$ \\
\hline
\end{tabular}

* Means followed by the same letter did not differ from each other by Tukey test at 0.05 . CV: coefficient of variation. $\mathrm{T} 1=100 \% \mathrm{KCl}$, $\mathrm{T} 2=87.5 \% \mathrm{KCl}+12.5 \% \mathrm{~K}_{2} \mathrm{SO}_{4} .2 \mathrm{MgSO}_{4}, \mathrm{~T} 3=75 \% \mathrm{KCl}+25 \% \mathrm{~K}_{2} \mathrm{SO}_{4} .2 \mathrm{MgSO}_{4}, \mathrm{~T} 4=50 \% \mathrm{KCl}+50 \% \mathrm{~K}_{2} \mathrm{SO}_{4} .2 \mathrm{MgSO}_{4}, \mathrm{~T}_{5}=25 \%$ $\mathrm{KCl}+75 \% \mathrm{~K}_{2} \mathrm{SO}_{4} \cdot 2 \mathrm{MgSO}_{4}, \mathrm{~T} 6=100 \% \mathrm{~K}_{2} \mathrm{SO}_{4} \cdot 2 \mathrm{MgSO}_{4}$

In addition, the installment becomes ideal in $\mathrm{K}$ management, since it is monovalent: it presents high losses by leaching in the latosols. K leaching because of groundwater contamination possibly can reduce producer profit. If $\mathrm{K}$ application is exceeded or not synchronized with the crop demand, this can reduce yield because the nutrient when in excess has its efficiency decreased, thereby increasing the risks of leaching K (QIU et al. al., 2014).

The second class, on the other hand, had a reduction of $23 \%$ when the fertilizer was fragmented. However, it is worth remembering that tubers quotations in the market are based according to the diameter, with the larger diameter (Special) being the most valued. The producer must consider all factors for decision making. The Special class corresponded to $45.1 \%$ of yield, followed by 27.6; 20.1; 5.6 and $1.5 \%$ of Second, Diverse, Discard and Doll classes yield, respectively (Table 4).

The Special class yield ranged from 14.2 to $17.65 \mathrm{t} \mathrm{ha}^{-1}$. Second and Diverse classes ranged from 8.37 to 11.38 and 6.1 to $9.08 \mathrm{t} \mathrm{ha}^{-1}$, respectively (Table 4). The total commercial productivity varied between 30.8 and $34.7 \mathrm{tha}^{-1}$.

In Ibicoara-BA, the $\mathrm{K}$ source proportion affected only the Discard class (Table 6).
Application of $100 \% \mathrm{KCl}$ had a lower amount of this class, being 3.9 times lower than the highest discard rate, occurring in plants fertilized with $75 \%$ $\mathrm{KCl}$ and $25 \% \quad \mathrm{~K}_{2} \mathrm{SO}_{4} \cdot 2 \mathrm{MgSO}_{4}$. Partitioning $\mathrm{K}$ fertilizer also affected only the Discard class (Table 7). The $\mathrm{K}$ division in two applications reduced the rate of discarded tubers by $31 \%$.

The $\mathrm{K}_{2} \mathrm{SO}_{4} \cdot 2 \mathrm{MgSO}_{4}$, by supplying three nutrients ( $\mathrm{K}, \mathrm{Mg}$ and $\mathrm{S})$, in an appropriate rate, may favor plant defense (HUBER; JONES, 2013), since equilibrium among nutrients in the environment results in higher absorption levels of some elements and, consequently, in better quality plants (SHAH et al., 2016). Hemmati and Mansoori (2016) observed that nutritional management has a significant effect on disease reduction. Therefore, it is observed that the adoption of adequate fertilization techniques and management favors crop success, cost reduction, and sustainability assurance.

The Special class corresponded to $39.9 \%$ of total yield, followed by $26.2 ; 29.3 ; 3.4$ and $1.2 \%$ of Second, Diverse, Discard and Doll classes yield, respectively. Special class ranged from 11.1 to 15.1 $\mathrm{t} \mathrm{ha} \mathrm{h}^{-1}$. Second and Diverse classes ranged from 7.6 to 10.1 and 9.1 to $10.4 \mathrm{t} \mathrm{ha}^{-1}$, respectively (Table 6). 
The total commercial productivity varied between 27.7 and $35 \mathrm{tha}^{-1}$.

Table 6. Potato tubers yield cultivated with $\mathrm{K}$ sources proportions $\left(\mathrm{KCl}\right.$ and $\left.\mathrm{K}_{2} \mathrm{SO}_{4} \cdot 2 \mathrm{MgSO}_{4}\right)$ in Ibicoara-BA.

\begin{tabular}{ccccccc}
\hline & & & & & Total \\
Treatments & Special & Second & Diverse & Doll & Discard & commercial \\
\hline 1 & & \multicolumn{7}{c}{$\mathrm{tha}^{-1}$} \\
2 & $11.11 \mathrm{a}^{*}$ & $7.57 \mathrm{a}$ & $9.10 \mathrm{a}$ & $0.29 \mathrm{a}$ & $0.61 \mathrm{a}$ & $27.78 \mathrm{a}$ \\
3 & $15.10 \mathrm{a}$ & $9.32 \mathrm{a}$ & $9.23 \mathrm{a}$ & $0.56 \mathrm{a}$ & $0.77 \mathrm{ab}$ & $33.65 \mathrm{a}$ \\
4 & $13.70 \mathrm{a}$ & $10.14 \mathrm{a}$ & $9.40 \mathrm{a}$ & $0,13 \mathrm{a}$ & $2.39 \mathrm{~b}$ & $33.24 \mathrm{a}$ \\
5 & $13.21 \mathrm{a}$ & $7.61 \mathrm{a}$ & $10.05 \mathrm{a}$ & $0.54 \mathrm{a}$ & $0.93 \mathrm{ab}$ & $30.87 \mathrm{a}$ \\
6 & $13.30 \mathrm{a}$ & $8.63 \mathrm{a}$ & $10.43 \mathrm{a}$ & $0.39 \mathrm{a}$ & $1.16 \mathrm{ab}$ & $32.36 \mathrm{a}$ \\
\hline
\end{tabular}

* Means followed by the same letter did not differ from each other by Tukey test at 0.05 . CV: coefficient of variation. T1 = $100 \% \mathrm{KCl}, \mathrm{T} 2=87.5 \% \mathrm{KCl}+12.5 \% \mathrm{~K}_{2} \mathrm{SO}_{4} \cdot 2 \mathrm{MgSO}_{4}, \mathrm{~T} 3=75 \% \mathrm{KCl}+25 \% \mathrm{~K}_{2} \mathrm{SO}_{4} \cdot 2 \mathrm{MgSO}_{4}, \mathrm{~T} 4=50 \% \mathrm{KCl}+50 \%$ $\mathrm{K}_{2} \mathrm{SO}_{4} \cdot 2 \mathrm{MgSO}_{4}, \mathrm{~T} 5=25 \% \mathrm{KCl}+75 \% \mathrm{~K}_{2} \mathrm{SO}_{4} \cdot 2 \mathrm{MgSO}_{4}, \mathrm{~T} 6=100 \% \mathrm{~K}_{2} \mathrm{SO}_{4} \cdot 2 \mathrm{MgSO}_{4}$.

Table 7. Potato tubers yield cultivated with or without $\mathrm{K}$ installments (100\% at planting or $50 \%$ at planting and $50 \%$ at tuberization beginning) in Ibicoara-BA.

\begin{tabular}{ccccccc}
\hline Treatments & Special & Second & Diverse & Doll & Discard & Total commercial \\
\hline \multicolumn{7}{c}{} \\
With & $13.56 \mathrm{a}^{*}$ & $8.77 \mathrm{a}$ & $9.54 \mathrm{a}$ & $0.42 \mathrm{a}$ & $0.94 \mathrm{a}$ & $31.87 \mathrm{a}$ \\
Without & $13.30 \mathrm{a}$ & $8.99 \mathrm{a}$ & $10.26 \mathrm{a}$ & $0.36 \mathrm{a}$ & $1.40 \mathrm{~b}$ & $32.55 \mathrm{a}$ \\
\hline
\end{tabular}

* Means followed by the same letter did not differ from each other by Tukey test at 0.05 . CV: coefficient of variation. $\mathrm{T} 1=100 \% \mathrm{KCl}$, $\mathrm{T} 2=87.5 \% \mathrm{KCl}+12.5 \% \mathrm{~K}_{2} \mathrm{SO}_{4} .2 \mathrm{MgSO}_{4}, \mathrm{~T} 3=75 \% \mathrm{KCl}+25 \% \mathrm{~K}_{2} \mathrm{SO}_{4} .2 \mathrm{MgSO}_{4}, \mathrm{~T} 4=50 \% \mathrm{KCl}+50 \% \mathrm{~K}_{2} \mathrm{SO}_{4} .2 \mathrm{MgSO}_{4}, \mathrm{~T} 5=25 \%$ $\mathrm{KCl}+75 \% \mathrm{~K}_{2} \mathrm{SO}_{4} \cdot 2 \mathrm{MgSO}_{4}, \mathrm{~T} 6=100 \% \mathrm{~K}_{2} \mathrm{SO}_{4} \cdot 2 \mathrm{MgSO}_{4}$.

The metabolic/physiological processes can explain the lower yield of the Special class in Ibicoara-BA. The higher stem number, and consequently, higher tubers number in Ibicoara-BA, reflected a higher segregation of photoassimilates among the tubers, causing a larger tubers number with smaller diameter, with consequently lower market prices (FILGUEIRA, 2008).

The productivity was similar between the two localities, despite marked differences in climate and soil type. Probably, the warm summer period of Ibicoara-BA, became limiting to the typical cultivar of temperate climate, even though it is the region where cultivation was conducted with more favorable weather conditions to potato cultivation, with the year period essential to decide the investments of the producers.

\section{Post-harvest in São Gotardo-MG Soluble Solids}

There was a reduction in tubers soluble solids with $100 \% \mathrm{KCl}$ when the fertilizers were parceled out (Table 8). Larger proportions of $\mathrm{KCl}$ have greater advantages when parceled out, because as the proportion of $\mathrm{K}_{2} \mathrm{SO}_{4} \cdot 2 \mathrm{MgSO}_{4}$ increased, the need for rate division is reduced. According to Khan et al. (2013), to avoid the $\mathrm{Cl}^{-}$adverse consequences in qualitative parameters, the soluble solids, $\mathrm{K}_{2} \mathrm{SO}_{4} \cdot 2 \mathrm{MgSO}_{4}$, would be preferred as a fertilizer source, as observed in the present study. Lower sucrose reduction is also related to the supplied $\mathrm{K}_{2} \mathrm{SO}_{4}$, leading to quality improvement (WATANABE et al., 2016).

\section{Starch}

An increase in starch content was observed when the cover was applied with $100 \%$ of $\mathrm{K}_{2} \mathrm{SO}_{4} .2 \mathrm{MgSO}_{4}$. Starch decreased at levels of $12.5 \%$ of $\mathrm{K}_{2} \mathrm{SO}_{4} .2 \mathrm{MgSO}_{4}+87.5 \% \mathrm{KCl}$ and $50 \%$ $\mathrm{K}_{2} \mathrm{SO}_{4} \cdot 2 \mathrm{MgSO}_{4}$ and $\mathrm{KCl}$. When comparing the $\mathrm{K}$ proportions, it was observed that, by performing the rate division, the $100 \% \mathrm{~K}_{2} \mathrm{SO}_{4} \cdot 2 \mathrm{MgSO}_{4}$ presented increases in the starch contents. On the other hand, with $12.5 \% \mathrm{~K}_{2} \mathrm{SO}_{4} .2 \mathrm{MgSO}_{4}+87.5 \% \mathrm{KCl}$ and $25 \%$ $\mathrm{KCl}+75 \% \mathrm{~K}_{2} \mathrm{SO}_{4} \cdot 2 \mathrm{MgSO}_{4}$, the highest starch contents were observed when coverage was not performed (Table 6). 
Table 8. Soluble Solids and Starch as function of $\mathrm{K}$ sources proportions $\left(\mathrm{KCl}\right.$ and $\left.\mathrm{K}_{2} \mathrm{SO}_{4} \cdot 2 \mathrm{MgSO}_{4}\right)$ and with or without $\mathrm{K}$ installments (100\% at planting or 50\% at planting and $50 \%$ at beginning of tuberization) in São Gotardo-MG

\begin{tabular}{|c|c|c|c|c|}
\hline \multirow{2}{*}{ Treatments } & \multicolumn{2}{|c|}{ Soluble Solids } & \multicolumn{2}{|c|}{ Starch } \\
\hline & With & Whitout & With & Whitout \\
\hline 1 & $12,86 \mathrm{aB}^{*}$ & $14,12 \mathrm{aAB}$ & $7,65 \mathrm{aAB}$ & $8,08 \mathrm{aAB}$ \\
\hline 2 & $14,17 \mathrm{bAB}$ & $15,74 \mathrm{aA}$ & $7,22 \mathrm{bAB}$ & $9,91 \mathrm{aA}$ \\
\hline 3 & $15,58 \mathrm{aA}$ & $14,12 \mathrm{bAB}$ & $6,21 \mathrm{aB}$ & $6,34 \mathrm{aB}$ \\
\hline 4 & $13,90 \mathrm{aAB}$ & $12,56 \mathrm{bB}$ & $6,42 \mathrm{bB}$ & $8,71 \mathrm{aAB}$ \\
\hline 5 & $14,41 \mathrm{aAB}$ & $13,31 \mathrm{aB}$ & $8,42 \mathrm{aAB}$ & $9,83 \mathrm{aA}$ \\
\hline 6 & $15,03 \mathrm{aA}$ & $14,23 \mathrm{aAB}$ & $9,47 \mathrm{aA}$ & $6,47 \mathrm{bB}$ \\
\hline
\end{tabular}

The total starch content is significantly affected by its genotype, environment and culture condition (BACH et al., 2013). The lower starch content reduces specific gravity, which has adverse consequences for human health such as obesity and cardiovascular disease, resulting from a greater retention in processed products such as French fries (KHAN et al., 2013).

Although 'Agate' is not intended for frying, it is not uncommon for consumers to utilize the tubers of this cultivar for this purpose, especially at lower cost and greater availability. Therefore, the management of potassium fertilization may contribute to the provision of better quality food.

\section{CONCLUSIONS}

The proportion of potassium fertilizer sources in São Gotardo-MG does not affect the vegetative development at 60 days after planting (DAP) and potato yield. In Ibicoara-BA, plants fertilized with $100 \% \mathrm{KCl}$ reduced the amount of discarded tubers and presented an accumulation of ADM $41 \%$ higher than the application of $50 \% \mathrm{KCl}$ and $50 \% \quad \mathrm{~K}_{2} \mathrm{SO}_{4} \cdot 2 \mathrm{MgSO}_{4}$. The $\mathrm{K}$ division is favorable to the Special tuber class in São GotardoMG and reduces the Discard class in Ibicoara-BA.

Most of the proportions between $\mathrm{K}_{2} \mathrm{SO}_{4} \cdot 2 \mathrm{MgSO}_{4}$ and $\mathrm{KCl}$ did not differ from exclusive use of $\mathrm{KCl}$ for quantitative parameters. On the other hand, qualitative factors such as starch and soluble solids are related to the application of $100 \%$ of $\mathrm{K}$ via $\mathrm{K}_{2} \mathrm{SO}_{4} \cdot 2 \mathrm{MgSO}_{4}$ in installments.

RESUMO: A batateira apresenta extraordinária capacidade produtiva, sendo a adubação um dos fatores essenciais para otimização do potencial das cultivares. O potássio $(\mathrm{K})$, nutriente mais absorvido e transportado pela cultura, interfere na produtividade e qualidade dos tubérculos. Apesar dos muitos esforços para melhoria do manejo geral e nutricional da cultura, informações como a fonte do $\mathrm{K}$ e o seu parcelamento ainda não estão bem elucidados, gerando dúvidas aos produtores quanto a tomada de decisão. Com isso, objetivou-se avaliar o desenvolvimento, produtividade e qualidade de batata em função de fontes e proporções de adubação potássica e seu parcelamento. Os ensaios foram conduzidos a campo com a variedade Ágata, nos municípios de Ibicoara - BA e de São Gotardo - MG. O delineamento foi em blocos casualizados, em fatorial $6 \mathrm{X} 2$ com 4 repetições. Os tratamentos consistiram na combinação das fontes cloreto de potássio e sulfato duplo de potássio e magnésio $\left(100 \% \mathrm{KCl} ; 87.5 \% \mathrm{KCl}+12.5 \% \mathrm{~K}_{2} \mathrm{SO}_{4} \cdot 2 \mathrm{MgSO}_{4} ; 75 \% \mathrm{KCl}+25 \% \mathrm{~K}_{2} \mathrm{SO}_{4} \cdot 2 \mathrm{MgSO}_{4}\right.$; $50 \% \mathrm{KCl}+50 \% \mathrm{~K}_{2} \mathrm{SO}_{4} \cdot 2 \mathrm{MgSO}_{4} ; 25 \% \mathrm{KCl}+75 \% \mathrm{~K}_{2} \mathrm{SO}_{4} \cdot 2 \mathrm{MgSO}_{4}$ e $100 \% \mathrm{~K}_{2} \mathrm{SO}_{4} \cdot 2 \mathrm{MgSO}_{4}$ ) e parcelamento ou não da quantidade de potássio recomendada (100\% no plantio ou $50 \%$ no plantio e $50 \%$ no início da tuberização). O desenvolvimento vegetativo aos 60 DAP e a produtividade da batateira não é afetado pela proporção entre fontes de fertilizante potássico em São Gotardo-MG. Por outro lado, em Ibicoara-BA, plantas adubadas com $100 \% \mathrm{KCl}$ reduziu a quantidade de tubérculos descartados e apresentaram acúmulo de massa seca de parte aérea (MSPA) $41 \%$ superior a aplicação de $50 \% \mathrm{KCl}$ e $50 \% \mathrm{~K}_{2} \mathrm{SO}_{4} \cdot 2 \mathrm{MgSO}_{4}$. O parcelamento do $\mathrm{K}$ é favorável a classe Especial de tubérculos, em São Gotardo e reduz a classe Descarte em Ibicoara-BA. A maioria das proporções entre $\mathrm{K}_{2} \mathrm{SO}_{4} \cdot 2 \mathrm{MgSO}_{4}$ com o $\mathrm{KCl}$ não diferiu do uso exclusivo do $\mathrm{KCl}$ para os parâmetros quantitativos. Por outro lado, fatores qualitativos como amido e sólidos solúveis estão relacionados a aplicação de $100 \%$ do $\mathrm{K}$ via $\mathrm{K}_{2} \mathrm{SO}_{4} \cdot 2 \mathrm{MgSO}_{4}$ parcelado. 
PALAVRAS-CHAVE: Solanum tuberosum. Sulfato duplo de potássio e magnésio. Cloreto de potássio.

\section{REFERENCES}

ACOSTA-ESTRADA, B.A.; GUTIÉRREZ-URIBE, J.A.; SERNA-SALDÍVAR, S.O. Boundphenolics in foods, a review. Food Chemistry, v. 152, p. 46-55, 2014. https://doi.org/10.1016/j.foodchem.2013.11.093

AGHAJANZADEH, M. R. T.; PARMAR, J. H. S.; HAWKESFORD, M. J.; KOK, L. J. Chloride and sulfate salinity differently affect biomass, mineral nutrient composition and expression of sulfate transport and assimilation genes in Brassica rapa. Plant Soil, v. 411, p. 319-332, 2017. https://doi.org/10.1007/s11104-0163026-7

AL-OBAIDI, M. A. J.; AHMED, H. M.; KHALIL, M. T. Role of Potassium Bearing Minerals in Desorption of Reserved Potassium in Some Soils of Northern Iraq. Journal of Agricultural Science and Technology, v. 4, p. 487-493, 2014.

ANSCHÜTZ, U.; BECKERA, D.; SHABAL, S. Going beyond nutrition: Regulation of potassium homoeostasis as a common denominator of plant adaptive responses to environment. Journal of Plant Physiology, v. 171, p. 670-687, 2014. https://doi.org/10.1016/j.jplph.2014.01.009

ARMENGAUD, P.; BREITLING, R.; AMTMANN, A. The potassium dependent transcriptome of Arabidopsis reveals a prominent role of jasmonic acid in nutrient signaling. Plant Physiology, v. 136, p. 2556-2576, 2004. https://doi.org/10.1104/pp.104.046482

BACH, S.; YADA, R. Y.; BIZIMUNGU, B.; FAN, M.; SULLIVAN, J. A. Genotype by environment interaction effects on starch content and digestibility in potato (Solanum tuberosum L.). Journal of Agriculture and Food Chemistry, v. 61, n. 16, p. 3941-3948, 2013. https://doi.org/10.1021/jf3030216

BENLLOCH-GONZALEZ, M.; ARQUERO, O.; MARIA, F. J.; BARRANCO, D.; BENLLOCH, M. K+ starvation inhibits water-stress-induced stomatal closure. Journal of Plant Physiology, v. 165, p. 623-630, 2008. https://doi.org/10.1016/j.jplph.2007.05.010

CARDOSO, A. D.; ALVARENGA, M. A. R.; MELO, T. L.; VIANA, A. E. S. Produtividade e qualidade de tubérculos de batata em função de doses e parcelamentos de nitrogênio e potássio. Ciência e Agrotecnologia, v. 31, n. 6, p. 1729-1736, 2007. https://doi.org/10.1590/S1413-70542007000600019

CHEN, W.; HE, Z. L.; YANG, X. E.; MISHRA, S.; STOFFELLA, P. J. Chlorine nutrition of higher plants: progress and perspectives. Journal of Plant Nutrition, v. 33, p. 943-952, 2010.

https://doi.org/10.1080/01904160903242417

DEMIDCHIK, V. Mechanisms and physiological roles of K+ efflux from root cells. Journal of Plant Physiology, v. 171, p. 696-707, 2014. https://doi.org/10.1016/j.jplph.2014.01.015

EZEKIEL, R.; SINGH, N.; SHARMA, S.; KAUR, A. Beneficial phytochemicals in potato-a review. Food Research International, v. 50, n. 2, p. 487-496, 2013. https://doi.org/10.1016/j.foodres.2011.04.025

FERNANDES, A. M.; SORATTO, R. P. Nutrição mineral, calagem e adubação da batateira. Botucatu/Itapetininga: FEPAF/ABBA, 2012. 121p.

FILGUEIRA, F. A. R. Novo manual de olericultura: Agrotecnologia moderna na producao e comercialização de hortalicas. 2 ed. Viçosa: UFV, 2008, 421 p. 
FRANCO-NAVARRO, J. D.; BRUMOS, J.; ROSALES, M. A.; CUBERO-FONT, P.; TALÓN, M.; COLMENERO-FLORES. Chloride regulates leaf cell size and water relations in tobacco plants. Journal of Experimental Botany, v. 67, n. 3, p. 873-891, 2016. https://doi.org/10.1093/jxb/erv502

HEMMATI, A. A.; MANSOORI, B. Sufficient application of NPK fertilizers: A practical and efficient strategy in the management of Verticillium wilt of potato var. Journal of Crop Protection, v. 5, n. 3, p. 343-348, 2016. https://doi.org/10.18869/modares.jcp.5.3.343

HUBER, D. M.; ARNY, D. C. Interactions of potassium with plant disease. In: MUNSON, R.D. (Ed.). Potassium in Agriculture, Madison: ASA/CSSA/SSA, 1985. p. 467-488.

KHAN, S. A.; MULVANEY, R. L.; ELLSWORTH, T. R. The potassium paradox: Implications for soil fertility, crop production and human health. Renewable Agriculture and Food Systems, v. 29, n. 1, p. 3-27, 2013. https://doi.org/10.1017/S1742170513000318

LAM, H. K.; MCADAM, S. A. M.; MCADAM, E. L.; ROSS, J. J. Evidence that chlorinated auxin is restricted to the Fabaceae but not to the Fabeae. Plant Physiology, v. 168, n. 3, p. 798-803, 2015.

https://doi.org/10.1104/pp.15.00410

NELSON, N. A. A photometric adaptation of Somogy method for determination of glucose. Journal of Biological Chemistry, v. 153, n. 1, p. 375-390, 1944.

QIU, S.; XIE, J.; ZHAO, S.; XU, X.; HOU, Y.; WANG, X.; ZHOU, W.; HE, P.; JOHNSTON, A. M.; CHRISTIE, P.; JIN, J. Long-term effects of potassium fertilization on yield, efficiency, and soil fertility status in a rain-fed maize system in northeast China. Field Crops Research, v. 163, p. 1-9, 2014.

https://doi.org/10.1016/j.fcr.2014.04.016

REICH M, SHAHBAZ M, PRAJAPATI DH, PARMAR S, HAWKESFORD MJ, DE KOK LJ. Interactions of sulfate with other nutrients as revealed by $\mathrm{H}_{2} \mathrm{~S}$ fumigation of Chinese cabbage. Frontiers in Plant Science, $v$. 7, p. 541, 2016. https://doi.org/10.3389/fpls.2016.00541

ROSOLEM, C. A.; CALONEGO, J. C. Phosphorus and potassium budget in the soil-plant system in crop rotations under no-till. Soil \& Tillage Research, v. 126, p. 127-133, 2013.

https://doi.org/10.1016/j.still.2012.08.003

SARDANS, J.; PEÑUELAS, J. Potassium: a neglected nutrient in global change. Global Ecology and Biogeography, v. 24, p. 261-275, 2015. https://doi.org/10.1111/geb.12259

SHAH, S. A; MOHAMMAD, W.; SHAHZADI, S.; ELAHI, R.; ALI, A.; BASIR, A.; HAROON, A. The effect of foliar application of urea, humic acid and micronutrients on potato crop. Iran Agricultural Research, v. 35, n. 1, p. 89-94, 2016.

SUN, A.; XU, Q.; XU, S.; SHEN, H.; SUN, J. Separation and analysis of chlorine isotopes in higher plants. Chemical Geology, v. 381, p. 21-25, 2014. https://doi.org/10.1016/j.chemgeo.2014.04.006

TÖFOLI, J. G.; MELO, P. C. T.; DOMINGUES, R. J.; FERRARI, J. T. Potato late blight and early blight: importancy, characteristics and sustainable management. Biológico, São Paulo, v. 75, n. 1, p. 33-40, 2013.

WANG, Z.; LU, J.; YANG, H.; ZHANG; X.; LUO, C.; ZHAO, Y. Resorption of nitrogen, phosphorus and potassium from leaves of lucerne stands of different ages. Plant Soil, v. 383, p. 301-312, 2014.

https://doi.org/10.1007/s11104-014-2166-x

WATANABE, K.; FUKUZAWA, Y.; KAWASAKI, S. I.; UENO, M.; KAWAMITSU, Y. Effects of Potassium Chloride and Potassium Sulfate on Sucrose Concentration in Sugarcane Juice under Pot Conditions. Sugar

Tech, v. 18, n. 3, p. 258-265, 2016. https://doi.org/10.1007/s12355-015-0392-z 
Potassium sources...

OLIVEIRA, R. C. et al.

ZÖRB, C.; SENBAYRAM, M.; PEITER, E. Potassium in agriculture; Status and perspectives. Journal of Plant Physiology, v. 171, n. 9, 656-669, 2014. https://doi.org/10.1016/j.jplph.2013.08.008 